\title{
Perilaku Nonlinier Pipa Elbow Bertekanan dengan Beban Termal dan In-Plane Bending
}

\author{
Nurcahya Nugraha ${ }^{1)}$, Asnawi Lubis ${ }^{2)^{*}}$, Ahmad Su'udi ${ }^{3)}$ \\ ${ }^{1,2,3)}$ Jurusan Teknik Mesin Fakultas Teknik Universitas Lampung \\ Jalan Professor Soemantri Brojonegoro No.1, Bandar Lampung, 35145, Indonesia
}

Naskah diterima 29 Juli 2019; direvisi 22 September 2019; disetujui 28 Oktober 2019

doi: https://doi.org/10.24843/JEM.2019.v12.i02.p06

\begin{abstract}
Abstrak
Pipa elbow adalah komponen yang penting pada sistem perpipaan. Pipa elbow memiliki fleksibilitas yang baik, sehingga dapat mengurangi tegangan akibat ekspansi termal. Beban yang diterima oleh pipa elbow adalah beban bending, beban termal dan tekanan internal. Beban bending menyebabkan ovalisasi pada pipa elbow. Jika tekanan internal ditambahkan, maka tekanan internal akan cenderung bertindak melawan efek yang disebabkan oleh beban bending dan menunjukkan perilaku nonlinear. Beban in-plane bending dan tekanan internal yang bekerja secara bersamaan pada ping elbow tidak menunjukkan perilaku nonlinier. Pada kondisi aktual, beban yang diterima oleh pipa elbow adalah beban termal yang memberikan efek cenderung sama seperti beban in-plane bending. Pada penelitian ini dilakukan analisis untuk menilai perilaku nonlinier pipa elbow yang diberikan beban termal dan tekanan internal dibandingkan dengan beban in-plane bending dan tekanan internal. Pada penelitian ini digunakan metode elemen hingga (ANSYS Mechanical APDL). Material yang dipakai adalah titanium alloy (Ti$6 \mathrm{Al}-4 \mathrm{~V}$ ) dan diasumsikan bersifat elastic-perfectly plastic. Hasil penelitian menunjukkan bahwa perilaku nonlinier hanya terjadi pada pembebanan in-plane bending dan tekanan internal. Sedangkan pada pembebanan termal dan tekanan internal tidak terjadi perilaku nonlinier. Pada pembebanan termal, tekanan internal memberikan efek yang searah dengan perpindahan yang disebabkan oleh beban termal. Pada pembebanan in-plane bending, tekanan internal memberikan efek yang berlawanan dengan perpindahan yang disebabkan oleh beban in-plane bending. Tegangan akibat beban in-plane bending lebih besar dibandingkan beban termal. Tekanan internal meningkatkan tegangan yang disebabkan pembebanan termal dan mengurangi tegangan yang disebabkan pembebanan in-plane bending.
\end{abstract}

Kata kunci: Pipa Elbow, Perilaku Nonlinier, Beban Termal, In-Plane Bending

\begin{abstract}
Piping elbow is an important component in a piping system. Piping elbow has good flexibility, so it can minimize stress due to thermal expansion. The loads received by the piping elbow are bending load, thermal load and internal pressure. The bending load causes ovalization on the piping elbow. If internal pressure is added, internal pressure will tend to act against the effects caused by bending load and show a nonlinear behaviour. The in-plane bending and internal pressures acting simultaneously on the piping elbow do not show nonlinear behavior. In actual conditions, the load received by piping elbow are thermal load which give the same effect as in-plane bending. In this study an analysis was conducted to evaluate nonlinear behavior of piping elbow under thermal load and internal pressure compared to in-plane bending load and internal pressure. This study used software based on finite element methods (ANSYS Mechanical APDL). The material used is titanium alloy (Ti-6Al-4V) which assumed behave elastic-perfectly plastic. The results of the study show that nonlinear behavior only occurs in in-plane bending load and internal pressure. Whereas for thermal load and internal pressure there is not nonlinear behavior. For thermal loading, internal pressure has the same effect on displacement caused by thermal load. For in-plane bending loading, internal pressure has the opposite effect on displacement caused by in-plane bending load. The stress due to in-plane bending load is greater than the thermal load. Internal pressure increases the stress due to thermal loading and reduces stress due to in-plane bending loading
\end{abstract}

Keywords: Piping Elbow, Nonlinear Behavior, Thermal Load, In-Plane Bending

\section{Pendahuluan}

Pada dunia industri, sistem perpipaan berfungsi untuk mengarahkan fluida dari suatu tempat ke tempat tertentu, misalnya pada industri air minum, pengolahan minyak, gas, pembangkit listrik tenaga uap dan pabrik kimia. Pada umumnya sistem perpipaan digunakan untuk mengalirkan cairan, gas atau uap yang memiliki karakteristik sifat fisik, kimia, tekanan dan temperatur tertentu. Perbedaan karakteristik ini yang menyebabkan sistem perpipaan harus diperhatikan ketika proses desain, analisis dan uji coba. Hal ini berguna untuk memastikan bahwa sistem perpipaan benar-benar aman untuk digunakan.
Kegagalan pada sistem perpipaan dapat memberikan efek negatif pada kegiatan industri maupun lingkungan sekitar industri. Kegagalan yang terjadi pada sistem perpipaan disebabkan oleh beban pada pipa yang melebihi batas beban maksimum. tegangan izin materialnya. Beban yang diterima pipa dapat berupa beban termal, aksial, torsi, bending dan tekanan internal maupun eksternal

Pada penerapannya, sistem perpipaan memiliki banyak komponen, seperti pipa lurus, elbow, tee, cross, dan reducer. Salah satu komponen yang banyak terdapat pada sistem perpipaan adalah pipa elbow atau pipa lengkung. Pipa elbow merupakan komponen penting pada sistem perpipaan yang 
berfungsi mengubah arah aliran fluida. Di samping itu pipa elbow memiliki fleksibilitas yang lebih tinggi dibandingkan pipa lurus dengan ukuran dan material yang ekivalen, sehingga pipa elbow dapat meminimalisir efek dari ekspansi termal, pergerakan seismik dan beban pada anchor. Flexibilitas pipa elbow dalam piping code $[1,2]$ diberikan oleh persamaan:

$$
k=\frac{1.65}{h}
$$

dimana, $h$ adalah faktor pipa atau karakteristik pipe bend yang diberikan oleh persamaan berikut:

$$
h=\frac{t R}{r^{2}}
$$

dimana, $t$ adalah tebal pipa, $R$ adalah radius kelengkungan pipa, dan $r$ adalah radius penampang pipa

Beban yang diterima oleh pipa elbow dapat berupa beban bending, beban termal dan tekanan internal. Beban bending menyebabkan ovalisasi dan tegangan yang tinggi pada daerah crown pipa elbow. Akan tetapi apabila tekanan internal diberikan pada pipa elbow yang sudah diberi beban bending, maka akan memberikan efek yang berlawanan dengan ovalisasi (pressure reduction effect) [3]. Artinya bahwa tekanan internal mengurangi tegangan akibat beban bending dan menurunkan fleksibilitasnya [4]. Pada kondisi aktual di lapangan, beban yang diterima oleh pipa elbow adalah beban termal. Pemberian beban termal pada pipa elbow, memberikan efek yang cenderung sama seperti pipa elbow yang diberi beban bending. Pemberian tekanan internal pada pipa elbow yang sudah diberi beban termal tentunya akan berefek pada pipa elbow. Yang menjadi pertanyaan adalah apakah efek akibat tekanan internal pada pipa elbow yang diberikan beban termal sama dengan efek tekanan internal pada pipa elbow yang diberikan beban bending.

Efek pemberian tekanan internal pada pipa elbow dapat menyebabkan perilaku nonlinier apabila penampang pipa tidak lingkaran sempurna, tapi misalnya berbentuk oval akibat beban bending yang diterimanya [4]. Tidak banyak penelitian mengenai pipa elbow yang dilaporkan dalam literature yang membahas perilaku nonlinier pipa elbow yang disebabkan oleh tekanan internal dan beban termal. Chattopadhyay [5], Chen [6] dan Michael [7] adalah sedikit dari peneliti yang membahas perilaku nonlinear pipa elbow dengan kombinasi beban bending dan internal pressure, mereka tidak membahas perilaku nonlinear untuk kombinasi beban termal dan pressure. Pada penelitian ini dilakukan analisis dan perbandingan perilaku nonlinier pada pipa elbow bertekanan yang diberikan beban termal dan perilaku nonlinier pada pipa elbow bertekanan yang diberikan beban in-plane bending. Selain perilaku nonlinier, dilakukan juga analisis dan perbandingan tegangan untuk kedua kasus pembebanan tersebut.

Pipa elbow yang diberikan beban termal dan inplane bending memiliki efek yang serupa, yaitu terjadi ovalisasi penampang. Hal ini yang menjadi hipotesis awal dan menjadi acuan bahwa pada pipa elbow yang diberikan beban termal dan tekanan internal serta pada pipa elbow yang diberikan beban in-plane bending dan tekanan internal memiliki perilaku nonlinier yang serupa.

Pada penelitian ini dilakukan analisis elemen hingga menggunakan software ANSYS Mechanical APDL. Pemodelan dan simulasi pipa elbow menggunakan shell element (SHELL181) yang diberikan beban termal, beban in-plane bending, dan tekanan internal. Pada penelitian ini hasil yang didapat adalah hubungan antara beban, perpindahan dan tegangan maksimum yang terjadi akibat perilaku nonlinier pipa elbow.

\section{Metode Penelitian}

Dalam penelitian ini digunakan software ANSYS Mechanical APDL yang berbasis metode elemen hingga. Secara garis besar, metode elemen hingga dengan ANSYS terdiri dari tiga tahap, yaitu Preprocessing, Solution dan Post-Processing.

Pada tahap preprocessing dilakukan pemodelan geometri, penentuan kondisi batas dan pemberian beban. Langkah awal pada tahap pemodelan geometri adalah penentuan parameter yang bertujuan untuk mempermudah perubahan dimensi dan sifat material. Parameter yang dipakai adalah sudut kelengkungan $\alpha$, radius pipa $r$, radius kelengkungan $R$, tebal pipa $t$, dan panjang pipa tangen (tengent pipe) L. Pipa elbow dimodelkan menjadi bentuk setengah pipa karena bentuknya yang simetris. Pada penelitian ini dibuat 5 variasi ketebalan pipa, sehingga terdapat 5 macam pemodelan. Pipa elbow yang digunakan memiliki ukuran diameter luar 457,2 mm, sudut kelengkungan $90^{\circ}$, panjang pipa tangen $1436,33 \mathrm{~mm}$. Parameter geometri pemodelan pipa elbow dapat dilihat pada Tabel 1.

Pada analisis ini pipa elbow diperlakukan sebagai shell dinding tipis, sehingga digunakan elemen shell (SHELL181). Type elemen ini mempunyai 4 node dengan 6 derajat kebebasan pada setiap node yaitu translasi pada arah sumbu $\mathrm{x}, \mathrm{y}$ dan $\mathrm{z}$ serta rotasi terhadap sumbu $\mathrm{x}, \mathrm{y}$ dan $\mathrm{z}$.

Properti material dipilih berdasarkan buku Mechanic of Materials Sixth Edition yaitu titanium alloy (Ti-6Al-4V). Untuk lebih jelasnya properti material yang digunakan dapat dilihat pada Tabel 2. Material diasumsikan bersifat elastic-perfectly plastic, namun untuk menghindari masalah konvergensi, modulus plastisitas diasumsikan sebesar $100 \mathrm{MPa}$. 
Tabel 1. Parameter Geometri Pemodelan.

\begin{tabular}{ccccccc}
\hline $\begin{array}{c}\text { Schedule } \\
\text { Number }\end{array}$ & $\begin{array}{c}\text { Diameter } \\
\text { dalam }(\mathrm{mm})\end{array}$ & $\begin{array}{c}\text { Jari-jari } \\
\text { pipa }(\mathrm{mm})\end{array}$ & $\begin{array}{c}\text { Ketebalan } \\
\text { pipa }(\mathrm{mm})\end{array}$ & $\begin{array}{c}\text { Jari-jari } \\
\text { kelengkungan } \\
(\mathrm{mm})\end{array}$ & $\begin{array}{c}\text { Rasio tebal } \\
\text { dan jari-jari }\end{array}$ & $\begin{array}{c}\text { Karakteristik } \\
\text { fleksibilitas }\end{array}$ \\
\hline Sch 5S & 448,81 & 226,5 & 4,19 & 679,51 & 0,018 & 0,056 \\
\hline Sch 10S & 447,64 & 226,21 & 4,77 & 678,63 & 0,021 & 0,063 \\
\hline Sch 10 & 444,5 & 225,42 & 6,35 & 676,27 & 0,028 & 0,085 \\
\hline Sch 20 & 441,35 & 224,63 & 7,92 & 673,91 & 0,035 & 0,106 \\
\hline Sch Std & 438,15 & 223,83 & 9,52 & 671,51 & 0,042 & 0,128 \\
\hline
\end{tabular}

pembebanan termal. Beban in-plane bending hanya bekerja pada daerah elastis material tersebut.

Tekanan internal yang diberikan sebesar $1 \mathrm{MPa}$.

Tabel 2. Properti Material.

\begin{tabular}{cccc}
\hline $\begin{array}{c}\text { Modulus } \\
\text { Elastisitas }\end{array}$ & $\begin{array}{c}\text { Tegangan } \\
\text { Luluh }\end{array}$ & $\begin{array}{c}\text { Poison } \\
\text { Ratio }\end{array}$ & $\begin{array}{c}\text { Koefisien } \\
\text { Ekspansi Termal }\end{array}$ \\
\hline $115 \mathrm{GPa}$ & $830 \mathrm{MPa}$ & 0,33 & $9,5 \times 10^{-6} /^{\circ} \mathrm{C}$ \\
\hline
\end{tabular}

Pada tahap meshing, bagian pipa lengkung dibagi atas 18 elemen pada arah keliling (hoop) dan 30 elemen pada arah longitudinal. Pada bagian pipa tangen digunakan 18 elemen pada arah keliling (hoop) dan 25 elemen pada arah longitudinal dengan ukuran elemen yang semakin kecil ke arah junction. Jumlah keseluruhan elemen adalah 1440 buah. Hasil meshing dapat dilihat pada Gambar 1 .

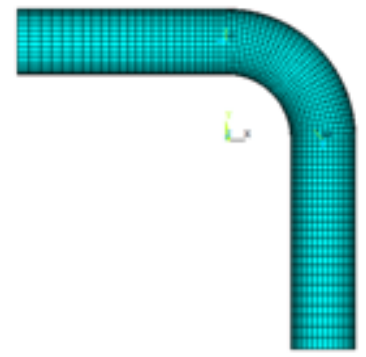

Gambar 1. Pemodelan elemen (meshing)

Pada pembebanan termal, kondisi batas yang diterapkan adalah translasi dan rotasi nol (fixed-fixed) untuk seluruh node pada ujung pipa tangen vertikal dan horizontal. Kondisi batas simetris diterapkan pada bidang pipa ebow (arah sumbu z). Sedangkan untuk pembebanan in-plane bending, translasi dan rotasi node pada ujung pipa tangen vertikal yang di fix dan beban bending diberikan pada ujung tangent horizontal (fix-free).

Pada tahap pembebanan diberikan pembebanan termal yang dikombinasikan dengan tekanan internal dan in-plane bending yang dikombinasikan dengan tekanan internal. Beban termal diberikan pada seluruh permukaan internal pipa elbow. Beban termal yang diberikan sebesar $150^{\circ} \mathrm{C}$. Sedangkan tekanan internal yang diberikan adalah $1 \mathrm{MPa}$. Pada tahap ini dilakukan beberapa langkah pembebanan untuk melihat ketidaklinieran (nonlinearity). Pada pembebanan termal dan tekanan internal dilakukan tiga kombinasi pembebanan, yaitu termal + pressure, pressure + termal dan termal \& pressure.

Beban in-plane bending diberikan pada ujung pipa tangen horizontal. Beban in-plane bending yang diberikan diperoleh dari reaksi tumpuan akibat
Pada tahap ini dilakukan beberapa langkah pembebanan untuk melihat ketaklinieran. Pada pembebanan in-plane bending dan tekanan internal dilakukan tiga kombinasi pembebanan, yaitu bending + pressure, pressure + bending dan bending \& pressure.

\section{Hasil dan Pembahasan}

\subsection{Perilaku Nonlinear.}

Gambar 2 menunjukkan typical hubungan beban perpindahan untuk kombinasi pembebanan termal dan tekanan internal. Dapat dilihat bahwa tekanan internal yang diberikan sesudah beban termal, sebelum beban termal dan bersamaan beban termal tidak menunjukkan perilaku nonlinear. Tekanan internal menambah besar displacement yang dihasilkan oleh beban termal. Begitu juga beban termal menambah besar displacement yang dihasilkan akibat beban tekanan internal. Dari Gambar 7 dapat dijelaskan bahwa grafik bersifat path independent yang berarti bahwa urutan pemberian beban termal dan tekanan internal tidak berpengaruh pada displacement akhir yang dihasilkan atau dengan arti lain bahwa displacement pada langkah pembebanan terakhir pada pembebanan termal + pressure, pressure + termal ataupun termal \& pressure besarnya sama.

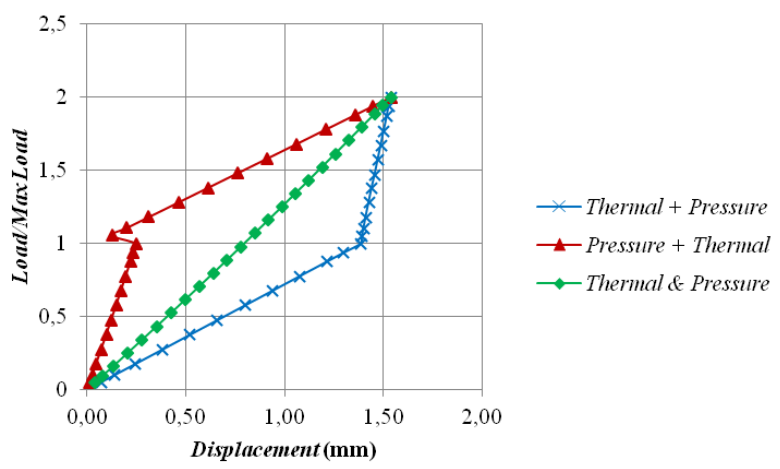

Gambar 2. Hubungan beban - displacement pada pipa elbow yang diberikan beban termal dan tekanan internal.

Gambar 3 menunjukkan typical hubungan beban vs. perpindahan node pada crown pipa elbow yang diberikan kombinasi pembebanan in-plane bending dan tekanan internal. Perilaku nonlinier dapat dilihat pada pembebanan bending yang diikuti beban tekanan internal. Hal ini adalah akibat dari tekanan internal yang bekerja pada elbow penampang oval yang 
dihasilkan oleh beban bending. Seperti diketahui, jika tekanan internal bekerja pada penampang yang tidak lingkaran sempurna, apakah pipa elbow atau pipa lurus, maka perpindahan radial node akan menunjukkan hubungan nonlinear dengan beban tekanan internal. Fenomena ini dikenal dengan "Haigh effect".

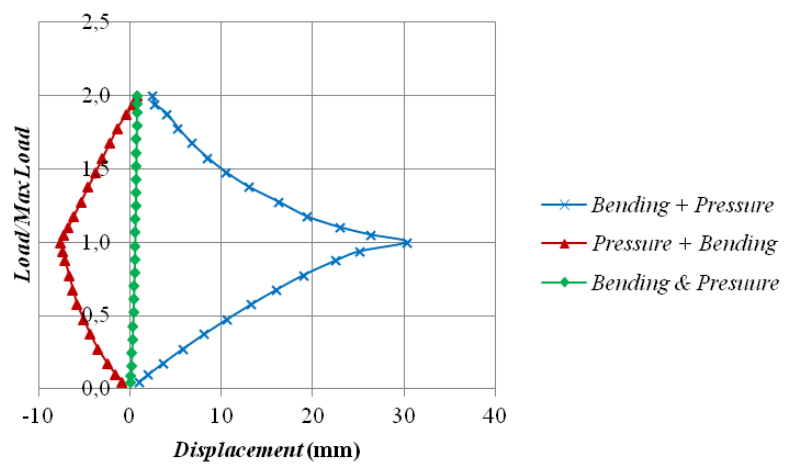

Gambar 3. Grafik perilaku nonlinier pada pipa elbow yang diberikan beban in-plane bending dan tekanan internal.

Nonlinearity juga dapat dilihat ketika beban internal pressure pertama-tama bekerja. Nonlinearity diduga adalah akibat dari "efek Bourdon" dimana ujung pipa elbow membuka ketika menerima tekanan internal. Beban bending yang bekerja setelah tekanan internal tidak menunjukkan nonlinearity. Begitu juga ketika beban bending dan tekanan internal bekerja bersama sama tidak menunjukkan hubungan nonlinear antara beban dan perpindahan radial.

Berbeda dengan kombinasi beban termal dan internal pressure, dimana displacement yang dihasilkan makin besar dengan urutan pembebanan, pada kombinasi beban bending dan internal pressure, memberikan efek berlawanan. Displacement akibat bending berkurang ketika kemudian diberikan beban internal pressure. Begitu juga displacement akibat internal pressure berkurang ketika kemudian disusul dengan beban bending. Pemberian tekanan internal juga berpengaruh terhadap besarnya displacement pada pipa elbow. Gambar 3 juga menunjukkan bahwa nonlinearity adalah path independent yang berarti bahwa urutan pembebanan antara in-plane bending dan tekanan internal tidak berpengaruh pada displacement akhir yang dihasilkan. Artinya bahwa displacement pada langkah pembebanan terakhir pada pembebanan bending + pressure, pressure + bending ataupun bending \& pressure besarnya tidak jauh berbeda.

\subsection{Perbandingan Tegangan}

Pemberian beban termal dan in-plane bending dilakukan pada pipa elbow dengan 5 variasi ketebalan, sedangkan radius kelengkungan dan radius penampang adalah konstant. Beban in-plane bending yang diberikan ekivalen dengan beban termal yang sudah diberikan sebelumnya, yaitu beban in-plane bending yang diperoleh melalui reaction solution akibat pembebanan termal. Data yang diambil adalah momen arah sumbu z pada node di ujung pipa tangen. Pada tahap postprocessing data tegangan yang diambil adalah tegangan von Mises maksimum
Gambar 4 menunjukkan grafik pengaruh karakter fleksibilitas ( $h)$ pipa elbow terhadap tegangan maksimum pada pembebanan termal dan in-plane bending. Gambar 4 menunjukkan bahwa karakter fleksibilitas lebih berpengaruh signifikan pada perubahan nilai tegangan maksimum pada pembebanan in-plane bending dibandingkan dengan pembebanan termal. Pada pembebanan in-plane bending, semakin besar nilai karakter fleksibilitas maka tegangan maksimum pada pipa elbow semakin kecil, atau dengan kata lain semakin tebal pipa elbow maka tegangan maksimum semakin kecil. Hal ini tidak terjadi pada pembebanan termal. Pada pembebanan termal, semakin besar nilai karakter fleksibilitas maka tegangan maksimum pada pipa elbow semakin besar.

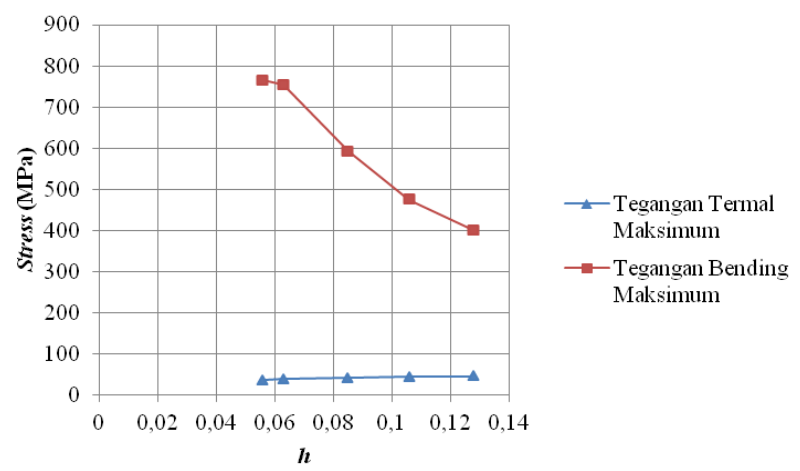

Gambar 4. Grafik tegangan maksimum pada pembebanan termal dan in-plane bending.

Dari Gambar 4, dapat dilihat bahwa tegangan yang terjadi akibat beban in-plane bending lebih besar daripada tegangan akibat beban termal. Hal ini disebabkan karena tegangan akibat beban in-plane bending merupakan primary stress. Primary stress adalah tegangan yang timbul dikarenakan pembebanan mekanik (gaya, momen). Sedangkan tegangan akibat beban termal merupakan secondary stress bersifat self-limiting yang muncul karena adanya restrain terhadap displacement. Jika diamati pada kondisi nyata di lapangan, pada pipa yang ditopang secara baik maka beban termal lebih dominan dibandingkan dengan beban in-plane bending. Sementara itu pada ASME piping code, untuk mendapatkan standar keamanan perancangan pipa elbow, beban mekanik lebih dominan dipertimbangkan. Hal ini menunjukkan bahwa standar perancangan pipa elbow pada ASME sudah sangat aman karena tegangan yang dihasilkan beban in-plane bending (beban mekanik) jauh di atas tegangan yang dihasilkan beban termal.

Gambar 5 menunjukkan bahwa tekanan internal memiliki pengaruh yang berbeda terhadap pipa elbow yang diberi beban termal dan in-plane bending. Pada pipa elbow yang diberi beban termal lalu diberi tekanan internal maka tegangan akibat beban termal bertambah karena pengaruh dari tekanan internal. Sedangkan pada pipa elbow yang diberi beban inplane bending lalu diberi tekanan internal maka tegangan akibat beban in-plane bending berkurang akibat pengaruh dari tekanan internal. Hal ini merupakan fenomena pressure reduction effect dimana tekanan internal memiliki efek yang berlawanan terhadap beban in-plane bending. 


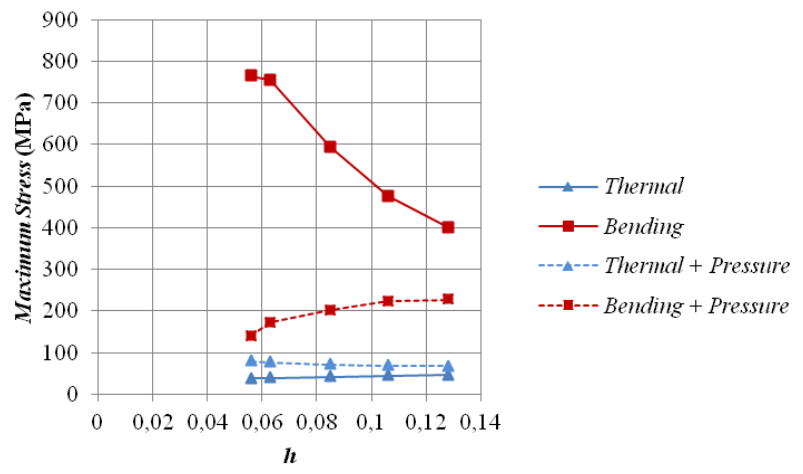

Gambar 10. Grafik pengaruh tekanan internal terhadap tegangan pipa elbow pada pembebanan termal dan in-plane bending.

\section{Simpulan}

Perilaku nonlinier pada pipa elbow terlihat jelas pada pembebanan bending yang diikuti pressure, sedangkan pada pembebanan termal tidak memperlihatkan perilaku nonlinier. Pada pembebanan termal yang diikuti oleh beban tekanan internal, displacement yang terjadi akibat beban termal bertambah ketika beban tekanan internal bekerja. Sedangkan pada pembebanan in-plane bending, tekanan internal memberikan efek berlawanan terhadap displacement yang disebabkan oleh beban in-plane bending.

Dengan beban yang ekivalen, tegangan yang berasal dari beban in-plane bending lebih besar dibandingkan dengan tegangan yang berasal dari beban termal. Pada pembebanan in-plane bending, semakin besar nilai karakteristik fleksibilitas $h$ semakin kecil tegangan maksimum pada pipa elbow. Sedangkan pada pembebanan termal, semakin besar nilai karakter fleksibilitas $h$, semakin besar tegangan maksimum pada pipa elbow. Tekanan internal memberikan pengaruh yang berlawanan terhadap pipa elbow yang diberi beban termal dan in-plane bending. Tekanan internal menambah tegangan pada pembebanan termal. Sedangkan pada pembebanan in-plane bending, tekanan internal mengurangi tegangan.

\section{Ucapan Terima Kasih}

Penulis mengucapkan terima kasih kepada Dr. Jamiatul Akmal atas diskusi dan saran perbaikan terhadap skripsi penulis pertama paper ini, dimana paper ini merupakan bagian dari skripsi tersebut.

\section{Daftar Pustaka}

[1] ASME B31.1, Power Piping. ASME Code for Pressure Piping, Edisi 2007.

[2] ASME B31.3, Process Piping. ASME Code for Pressure Piping, Edisi 2002.

[3] Lubis, A., and J. Akmal, 2006, Nonlinear Analysis of Pressurized Piping Elbows subjected to Out-ofPlane Bending, Key Engineering Materials, Vol 306-308, 351-356.
[4] Lubis, A., and J.T. Boyle, 2004, The Pressure Reduction Effect in Smooth Piping Elbows Revisited, International Journal of Pressure Vessels and Piping, Vol 81, 119-125.

[5] Chattopadhyay, J., 2002, The Effect of Internal Pressure on In-Plane Collapse Moment of Elbows, Nuclear Engineering and Design, Vol 212, 133144.

[6] Chen, H., 2011, Shakedown and limit Analysis of $90^{\circ}$ Pipe Bends Under Internal Pressure, Cyclic InPlane Bending and Cyclic Thermal Loading, International Journal of Pressure Vessels and Piping, Vol 88, 213-222.

[7] Michael, T.C., 2011, Effect of Ovality and Variable Wall Thickness on Collapse Loads in Pipe Bends Subjected to In-Plane Bending Closing Moment, Engineering Fracture Mechanics, Vol 79, 138-148. 